
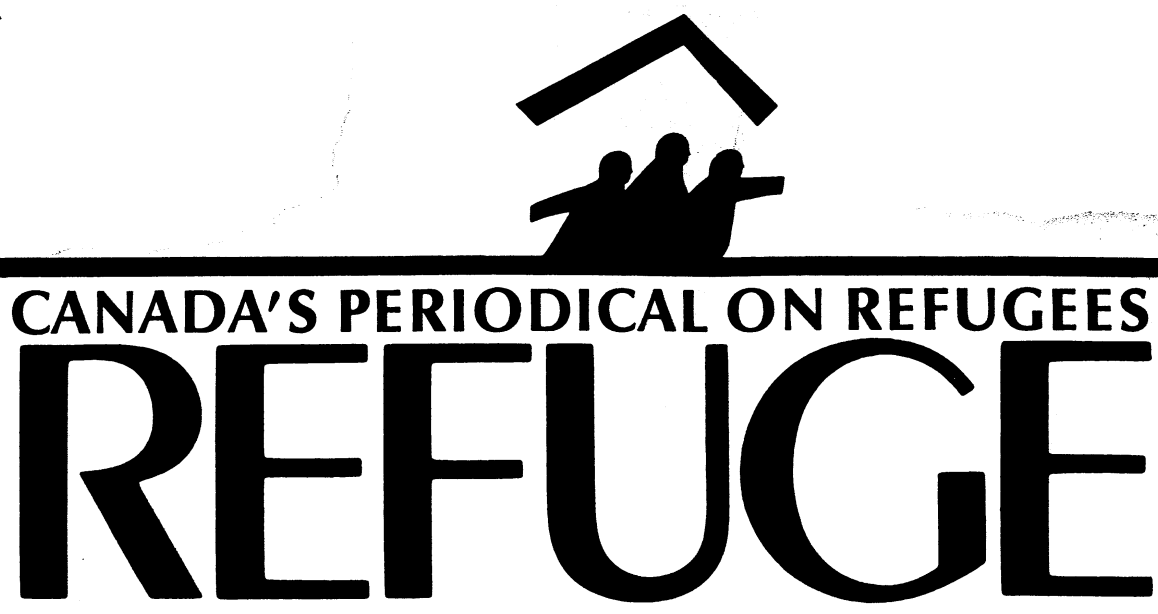

Vol. 5 , No. 4

\title{
Central American Refugees: Resettlement Needs and Solutions
}

May 1986

In the last decade, more than $1,600,000$ Central Americans have become refugees. Most of them are Salvadoreans and Guatemalans fleeing military repression. What is their destination? Most Guatemalans cross the border over to Mexico. Some of them "make it" to the United States, where they join the army of "illegals". Salvadoreans move in various directions: Nicaragua, Costa Rica, Panama, Belize, Honduras, Mexico and the United States. Some of these countries (Honduras and Mexico) place refugees in camps. Other countries (Nicaragua, Costa Rica, Panama and Belize) offer so-called "durable solutions" projects designed to make refugees self-sufficient. Guatemala does not recognize refugees. Mexico, in addition to maintaining camps, implements some agricultural projects for Guatemalans. Many of these refugees, with or without legal status, in camps or integrated into projects, apply for third country resettlement in Canada or Australia. Why do so many refugees prefer settlement in distant countries in spite of the language barrier and problems of cultural adaptation they will have to face? What are the problems with "regional resettlement"?

Sandra Pentland and Denis Racicot discuss violation of human rights of Salvadorean refugees in Honduran camps: intimidation, rape, murder and arrests are practised by the Honduran army. Pentland and Racicot analyse abuse of refugee rights from the point of view of the geo-political interests of the United States. Refugee camps at the border of Honduras and $\mathrm{El}$ Salvador interfere with U.S. plans for military operations in the area. This explains the constant pressure placed on refugees to move to other camps. Resistance by the refugee population to relocation plans provokes attacks and arrests of some Salvadoreans who are accused of supporting Salvadorean guerrillas. The article focuses on the August 29, 1985, attack on the Colomoncagua camp and consequent events.

The situation in Costa Rica does not look as bleak. By and large, lives of Salvadorean refugees are not in danger. They are allowed freedom of movement inside the country and a chance to become self-sufficient through "durable solutions" projects. However, Tanya Basok argues that these projects have not been viable. Some of the reasons for the failure are due to administrative errors which could be corrected. However, without the UNHCR emergency aid (which was discontinued in December 1985), only a small number of projects can be implemented, leaving most of the Salvadorean refugees with no means of economic survival.

How does Canada respond to this refugec crisis? There is no Canadian Embassy in Honduras and no Canadian immigration officers in the camps. Thus, it is extremely

difficult for Salvadoreans in Honduras to migrate to Canada. In Costa Rica the situation is somewhat better: at least, there is a possibility to apply. However, last year the quota for the region served by the Canadian Embassy in San Jose (which includes El Salvador, Nicaragua, Panama and Costa Rica) was 1,025 people. Some 200-250 refugees were from Costa Rica and they included not only Salvadoreans, but also Nicaraguans, Cubans and Guatemalans.

Another way of immigrating to Canada is through an in-land status determination procedure which, according to Charles Smith, is inefficient and, in many cases, unfair. He criticizes this procedure through which four out of five claimants get rejected because they are perceived as "economic immigrants". Smith argues that most of the Central Americans in Montreal are not "economic immigrants" but have a valid claim for refugee status.

What are the solutions, then? Improved security and protection measures in Honduran camps, more development funds directed towards "durable solutions" projects, increased immigration levels and a fair and more efficient refugee status determination procedure.

Tanya Basok

\section{IN THIS ISSUE:}

Salvadorean Refugees in Honduras by Sandra Pentland and Denis Racicot

How Durable Are the "Durable Solutions" Projects for Salvadorean Refugees in Costa Rica? by Tanya Basok

Trials and Errors: The Experience of Central American Refugees in Montreal by Charles D. Smith page 3

page 7

page 10 


\title{
How Durable Are the "Durable Solutions" Projects for Salvadorean Refugees in Costa Rica?
}

\author{
by Tanya Basok
}

Resettlement of refugees in developing countries is a complex matter. Can Third World countries provide a viable solution to refugee problems? From the point of view of moral responsibilities, Third World countries' governments face a dilemma. On the one hand, these governments are responsible for their own unemployed and under-employed. Offering economic support to refugees may mean denying it to needy nationals. Jobs taken up by refugees may mean more unemployment among the local population. On the other hand, by accepting refugees, governments thus assume responsibilities for the refugees' well-being. This sense of moral duty is also backed by the international law which receiving countries subscribe to once they sign the 1951 Convention and the 1967 Protocol on refugees.

The "durable solutions" approach was adopted as an answer to this dilemma. "Durable solutions" are measures taken towards the systematic and organized creation of productive activities which ensure that the refugees become economically self-sufficient, whether individually or collectively. More specifically, they are small businesses, artisanal or industrial shops and mediumsize farming projects. A UNHCR document outlines the advantages of the approach:

- Self-sufficiency projects are the ultimate aim of UNHCR as they allow the refugees to become independent of emergency assitance and be productively integrated in the receiving community.

- In the under-developed countries with serious unemployment problems, selfsufficiency projects offer the best alternative for the refugees' work problem.

- For the receiving country, these durable solutions are a contribution to the national economy, particularly the projects which include both nationals and refugees.

- Every durable solution is at the same time a very fruitful experience for the refugee which will become an asset when the conditions in his country of origin permit his return.

The "durable solutions" approach was applied to Salvadorean refugees in Costa Rica.

\section{Projects for Salvadorean Refugees in Costa Rica: A Background}

The influx of Salvadorean refugees to Costa Rica started in 1980 with 200 peasants occupying the Costa Rican Embassy in San Salvador. These refugees were originally settled on El Murciélago farm, in the north of Costa Rica, and then moved to what became known as the Los Angeles project. Refugee movement was a response to conditions of civil war and associated political repression and violence aimed especially at the civilian population. Between April 1980 and January 1982 (the worst years of the civil war), over 30,000 deaths were reported. It was estimated that 500,000 refugees had left El Salvador before 1982 to go to other Central American countries, Mexico and the United States.

Between 1980 and 1983, an average of 9,000 Salvadoreans per year arrived in Costa Rica through legal and illegal channels; 30,000 of them stayed there Only 10,000, however, had legal status and as such were attended by the UNHCR. In 1983 , the influx of Salvadorean refugees to Costa Rica stopped as a result of the government's imposition of strict requirements on those wishing to come to Costa Rica as tourists (this is a usual avenue for refugee claimants).

Although by 1977 Costa Rica had signed the 1951 UN Convention and the 1967 Protocol on refugees, it was not until October 1980 that a law, defining criteria for refugee status, was produced and put into practice. According to this law, a refugee claimant had to demonstrate proo of being persecuted for reasons of race, religion, nationality or belonging to a certain political or social group. Prior to 1980 , refugees recognized by the UNHCR had been subject to labour legislation for foreigners in general which allowed them to work as long as they did not replace national labour. In 1980, when refugees became legally recognized, their participation in the labour market became limited to incorporation into projects financed by the UNHCR. A memorandum of the UNHCR states:
In principle Costa Rica established that a refugee has no right to work. This, however, has not been interpreted as an absolute prohibition on the part of national authorities, but rather as a protection measure for the national labour force.

Refugees were allowed to work only in selfsufficient businesses financed by the UNHCR and approved by the National Commission for Refugees. The Episcopalian Church of Costa Rica was the first national non-governmental agency to become involved in resettlement of Salvadorean refugees. Later, other voluntary agencies, such as the Costa Rican Red Cross, Caritas, YMCA and OARS (Office of Refugee Orientation and Social Assistance), started developing and implementing projects. In December 1980 , CONAPARE (National Commission for Refugees) assumed the function of "establishing policies necessary for the development of programmes and projects related to refugees which would have to be followed by state institutions as well as non-government sectors participating in this field". All projects designed by voluntary agencies were required to get approval from CONAPARE for implementation.

A great number of Salvadoreans became integrated into these projects. In 1984, for instance, Caritas was administering 50 projects with 519 beneficiaries, 300 of whom were Salvadoreans. The YMCA was managing two urban projects with 20 members. The Episcopalian Church was in charge of 25 , mainly agricultural and dairy, projects with 600 recipients, 550 of whom were Salvadoreans. And OARS was administering 43 projects which involved 4,000 refugees, 3,950 of whom were Salvadoreans. In 1984, the UNHCR provided $\$ 1,579,000$ in support of these projects. Apart from the UNHCR, other international agencies, such as Swedish Free Church Aid, Church World Service, Latin American Project Council and Bread for Peace, offered their assistance.

\section{Why Do Most Projects Fail?}

Although significant funds and efforts were employed for these so-called "durable 
solutions" projects, most of them did not prove to be very "durable". A study undertaken by CONAPARE in 1983 demonstrated that out of 145 projects registered at this agency, $22(15.17 \%)$ had failed, $22(15.17 \%)$ were in "irregular" conditions, $30(20.69 \%)$ were inactive 1 and 71 (48.57\%) were active. Among the active projects only 17 (or $13.1 \%$ of all the projects) had become self-sufficient. The study also showed that the highest survival rate was found in agricultural activities: 17 of the 21 agricultural projects were active. The highest failure rate was found among mechanical, metallurgical, painting and other types of urban workshops: out of 12 workshops, 4 had failed, in comparison with 1 failure in agriculture. In 1983, Caritas of Costa Rica reported that out of 82 projects implemented by them $69 \%$ had failed. As can be seen, not too many projects had been successful. What then are the causes of their failure?

Three sets of causes can be identified. They relate to: 1) refugees; 2) implementing agencies; and/or 3) the Costa Rican government.

The refugees are often blamed by the implementing agencies' representatives and government officials for the failure of the projects. It is argued by them that the Salvadorean refugees in Costa Rica are of peasant origin, that they have worked only as wage-labourers and never have had business management experience, that they lack technical skills, that they are individualistic and therefore resist working in cooperative projects, that they do not get along with each other, that they are "irresponsible" and that they desert projects to go to third countries or back to El Salvador.

As indicated in a recent study by Luis Carballo, only $18.2 \%$ of a sample of Salvadorean refugees residing in Costa Rica used to work in agriculture, over one-quarter of the Salvadoreans in this sample had been self-employed, $5.8 \%$ had been employees, $8.4 \%$ worked in family businesses and $38 \%$ used to be salaried workers in their country of origin. In other words, almost one-third of the Salvadorean population in Costa Rica does have some skills necessary for managing

1 Projects in "irregular conditions" are those on which the agency has no information, and inactive projects are those which are in the process of implementation or restructuring and have not yet started or renewed activities. an enterprise. As far as technical skills are concerned, it is true that often refugees were forced into occupations in which they had no previous experience. Why this occurred is explained later in the article. A new approach taken by the agencies was to make training in both technical skills and administration an integral part of project implementation.

The individualistic attitude of Salvadorean refugees is questionable. It should be remembered that many refugees come from areas in El Salvador where "comunidades de base" or grass-root Christian communities organized into agricultural cooperatives were being formed since the early 1970 s. One can also mention the success of Salvadorean rural cooperatives in Nicaragua.

The decision to migrate to a third country or to return to El Salvador can be regarded as a direct result of the near-impossibility for Salvadorean refugees of finding decent living conditions in Costa Rica. Thus it may be argued that refugees deserted the projects because they did not find them viable and not vice versa.

The high failure rate of refugee projects can also be explained by the mistake committed by the implementing agencies. Two causal factors can be identified: first, mismanagement of the projects; and second, paternalistic treatment of the refugees by the implementing agencies. Projects were often implemented without prior analysis of the climatic, market, soil and other conditions. Out-dated technology contributing to low productivity was purchased. Technical expertise on hybrids, fertilizers and pesticides was not always available to project members. As for the problem of paternalistic treatment, refugee integrated into the projects often complained of being totally controlled by the representatives of the agencies. This led to a feeling of dependency and loss of motivation by the beneficiaries.

Finally, some of these failures can be attributed to policies adopted by the Costa Rican government. As it was mentioned earlier, CONAPARE is in charge of selecting projects to be implemented. The following criteria are used by the agency:

1. Projects are not to displace the national labour force, nor create immediate competition with established businesses;

2. Projects are to help bring foreign currency to the country;

3. Projects are to contribute to import substitution;
4. Projects are to employ national rather than imported primary resources;

5. Projects are to take advantage of manual, cultural and folkloric skills of the beneficiaries; and

6. Projects are to support the tendency of decentralization by being located outside the metropolitan area of San Jose.

Some of these criteria are problematic. Given the projects' low capital investment, they could only present competition to the local informal sector. It seems that in trying to protect the latter, the government authorized those projects which were in a disadvantageous position vis-a-vis the local large capitalist sector.

If one examines the lists of agricultural projects implemented by various agencies, one can see that most of them are cattleraising. At the same time, cattle-raising is the most concentrated and competitive agricultural business in Costa Rica. In the last 25 years, cattle-raising experienced considerable growth. While in 1955 , land under pasture constituted $39 \%$ of the agricultural area, in 1973 it was $50 \%$. The number of cattle head grew 25 times in that period. In 1973 cattle-raising farms under 20 hectares constituted $51 \%$ of all agricultural farms and occupied $6 \%$ of the land, while farms of 1,000 hectares or more, which constituted $0.7 \%$ of the farms occupied $23 \%$ of the land. In the last several years land under cattle has been getting more and more concentrated. For small, newly formed projects it is extremely difficult to compete with large cattle-raising farms.

The last criterion is also unfavourable to refugees. Many of the implemented projects are non-agricultural. Marketing conditions for goods and services provided by them are much better in the Central Valley region where about three-quarters of the local population resides. Some projects, being located far away from markets, suffer high transportation costs.

And finally, the first criterion, which imposes strict selection procedures, often goes counter to the criterion which encourages use of the refugees' technical skills. Rather than allowing refugees to choose the occupations of their liking and in which they have had experience, CONAPARE forces them into those workshops which will present no danger to local labour.

One CONAPARE study states that many members prefered to abandon the projects just before they reached self-sufficiency 
This occured because the salaries they expected to receive from these projects were lower than the UNHCR assistance offered to them until the project reached self-sufficiency. It is this seemingly rational behaviour of refugees that the CONAPARE study coined "irresponsible" (see above). It is often argued that prolonged emergency assistance by the UNHCR creates a "dependent" population unwilling to work.

Presently, this "problem" no longer exists since UNHCR emergency assistance was discontinued to all Salvadorean refugees in Costa Rica in December 1985. There is a greater incentive for the refugees to stay in the projects. On the other hand, the burden of providing subsistence to the project beneficiaries has shifted entirely to implementing agencies. The latter are required to offer more financial assistance per project and this results in the decline in the number of businesses these agencies are capable of implementing. For instance, the number of projects administered by the Episcopalian Church has decreased from 18 to 7 in the last year.

While the UNHCR solved the problem of a "dependent population", the Costa Rican government is not absorbing those "independent" wage-labourers who are not integrated into projects. In September 1984, a law allowing Salvadorean refugees to work was passed. However, it does not mean that a refugee can apply for the job of his choice. Instead, he has to find a job, get a letter from his employer and then apply for a permit to PRIMAS (Programa para Refugiados del Instituto Mixto de Ayuda Social). He then has to wait three to four months to get his application approved.

This procedure is in accordance with the Costa Rican policy of protecting the national labour force. According to the Labour Code of the country, a firm is to employ workers at least $90 \%$ of whom should be Costa Rican, who should receive at least $85 \%$ of the salaries. Thus, before granting a permit for work to an applicant, PRIMAS officials make sure that these conditions are observed. Of course, no employer is willing to wait for three or four months for a potential worker to get a permit. Given that a permit is often denied, a refugee loses three or four months awaiting a permit and not looking for any other job.

Why does the Costa Rican government fail to fulfil its responsibilities towards Salvadorean refugees? Certain justifications can be provided. Starting in 1979, the economic crisis in Costa Rica became evident. Between the beginning of 1980 and March 1982, the number of openly unemployed people more than doubled: it rose from 35,00 to 79,000 people. While in 1980 only $5 \%$ of the population of the country was unemployed, by 1983 the unemployment rate had reached $8.9 \%$. While in July 1979, 246,000 people faced employment problems, by 1982 the number had risen to 481,000 . The crisis hit the urban labour force relatively harder. In July 1983, the open unemployment rate in rural areas was $8.3 \%$ and, in urban areas, $12.2 \%$. Salaried workers were the major victims of unemployment as $51 \%$ of those who lost their jobs in 1980-82 were in that category. Given the growing unemployment in Costa Rica, it is clear that refugees are in direct competition for jobs with the local labour force.

In sum, most of the "durable solutions" projects for Salvadorean refugees in Costa Rica have failed. Some causes have to do with the refugees' lack of technical and administrative skills. These shortcomings can be overcome by offering training courses to project beneficiaries. Most errors committed by the agencies have by now been acknowledged by them and agencies are adopting a more rational research and planning approach to project implementation.

The Costa Rican government policy towards economic integration of the refugees presents more serious problems. The government cannot open doors to salaried jobs to refugees without endangering the national labour force. Therefore, while de jure refugees have a right to work, de facto their access to jobs is blocked by bureaucratic procedures. At the same time, without UNHCR emergency assistance, voluntary agencies can implement a limited number of projects.

What is to be done with those refugees who are neither incorporated into projects nor allowed to work for wages? There are two alternatives: directing more development funds into the projects for Salvadorean refugees in Costa Rica and/or increasing immigration to third countries. Canadian government and voluntary agencics can play an important role in both solutions.

Tanya Basok, a doctoral candidate in Sociology affiliated with the Refugee Documentation Project at York University, is presently in Costa Rica undertaking research on the resettlement of Salvadorean refugees.

\section{News Digest}

- Historians, conflict researchers as well as specialists in public international law are involved in a major refugee research project launched by the Department of History, University of Lund, Sweden. The focus of the project is on the period 1943-1954. Although the problem of uprooted Europeans will be central to the study, the latter will not be limited to Europe and wil analyse also U.S. refugee policy during this period. For further information please contact Professor Göran Rystad, Department of History, University of Lund, Magle Lilla Kyrkogata 9 A, S-223 51 Lund, Sweden.

- For ten years Connexions has acted as a nation-wide forum for the social change community in Canada. It has now launched the Connexions Directory of Canadian Organizations for Social Justice. The Directory includes address and telephone listings for over 1,500 groups working for social change. It will be updated annually. The Connexions Directory is available for $\$ 17.95$ from Connexions, 427 Bloor Street West, Toronto, Ontario, Canada M5S $1 \mathrm{X7}$, Tel.: (416) 960-3903.

- The Center for Migration Studies is publishing a special Spring issue of the International Migration Review focusing on refugee assistance and policy issues. This special issue, with an introduction by Dennis Gallagher of the Refugee Policy Group, will contain an impressive collection of articles on the following topics: refugee movements, asylum and protection, refugee issues in developing countries, and adjustment and resettlement. To order copies contact CMS, 209 Flagg Place, Staten Island, New York 10304, U.S.A.

- An annual publication of the U.S. Committee for Refugees, the World Refugee Survey includes extensive country reports, statistics, a directory of agencies and organizations working to meet refugees' needs, and a bibliography. The 1985 Survey includes contrasting views on U.S. asylum policy, articles on the "land Vietnamese" in Thailand, the situation of refugees from Chad, the protection of undocumented Salvadoreans in the United States, a personal account of the refugee situation in the Sudan, a look at the role of black Americans in helping refugees, and updates on refugee women and Soviet Jews. Single copies of the Survey sell for U.S.\$6.00. All requests for surveys should be sent to Gary Young, U.S. Committee for Refugees, 815 15th St., N.W., Suite 610, Washington, D.C. 20005, U.S.A. 
book writing style would be well served by an unacademic (dare we say journalistic?) narrative that openly uses the chronology of her time in the Sudan as a framework. And we could use a more visually descriptive sense of people and places.

The weaknesses of Harrell-Bond's study disappear in the awesomeness of her achievement. She has provided a point of beginning to all the players -- donors, private and governmental, administrators and, most of all, the recipients of policy, the refugees and their hosts -- to imagine a kind of help that is unimposed. Then the "giving" would look more like sharing and the "Haves" would concede to the "Havenots" some of that asset valued most: power.

Dawn MacDonald is a journalist who has recently returned from a fact-finding trip to the Ogaden desert region of Ethiopia where the UNHCR oversees a $\$ 40$ million recovery programme for returning Somali refugees. She wishes she had read Dr. Harrell-Bond's book prior to her journey.

\section{Renato Camarda \\ Forced to Move}

Introduction by Ronald V. Dellums

Edited by David Loeb and Susan Hansell

Translated by Susan Hansell

and Carmen Alegría

San Francisco: Solidarity

Publications, 1985

Out of the Ashes: The Lives and

Hopes of Refugees From $\mathrm{El}$

Salvador and Guatemala

London: EI Salvador Committee for

Human Rights, Guatemala Committee

for Human Rights, War on Want

Campaign Ltd., 1985

\section{by Tanya Basok}

Forced to Move and Out of the Ashes, two recent books on Central American refugees, complement one another in several ways. Forced to Move focuses only on Salvadorean refugees, mainly in Honduras. Out of the Ashes describes the situation of Salvadoreans and Guatemalans who seek asylum in other Central American countries, Mexico and the United States.

Forced to Move is based on testimonies by refugees, volunteers, doctors, nurses, priests, Honduran solidarity workers, UNHCR representatives and others. Except for a short introduction, chronology of the crisis and the update at the end of the book, there are no interventions by the author. The reader faces the task of reconstructing events and forming a picture of camp life from scattered bits of information revealed in testimonies. Out of the Ashes, on the other hand, offers a precise and succinct summary of the refugee situation through a more detached narrative. Out of the Ashes is informative, while the other book is very moving. The former appeals to reason, the latter to emotion.

One needs only compare the titles of these two books in order to understand the difference in their focuses. The title "Forced to Move" brings out images of repression, violence and coercion. There is a photo of a family (mother, father and two children) on the cover. Next to them stands a soldier holding a gun. Forced to Move is a collection of stories about why Salvadoreans had to abandon their homeland, why and how they were relocated against their will from La Virtud camp to Mesa Grande and why they were being forced to move from Colomoncagua and Mesa Grande to yet another area in 1983. It is a textbook of human suffering.

By comparison, Out of the Ashes is a statement of hope, of resurrection and of reconstruction of the lives of refugees. In contrast to the deadly image of the gun, the cover of Out of the Ashes presents symbols of life and hope: green trees, blooming flowers, women cooking food, people wearing brightly-coloured clothes. The book is an ode to human strength and resistance in the face of overwhelming problems. It portrays rebuilding of the society under the difficult conditions of camp life. Refugees do not give up but, instead, organize literacy classes, carpentry, hammock-making, pottery and other workshops. They cultivate land and form committees. Once a week they call a general assembly of all camp residents.

There are occasional references to these aspects of the refugee life in Forced to Move, but they are rare. There are photos of religious ceremonies, theatre performances and classes for children in the chapter on life in the camp. However, the text which accompanies these photos covers repression of refugees and solidarity workers by the Honduran army. A photo on page 43 depicts women during the elections for the refugee coordinating committees. Information on these committees is missing, however. While a few pages are devoted to the determination of the Salvadoreans to work, learn and produce in the camp, most of the book is a denunciation of violence aimed at innocent people by the Salvadorean and Honduran armies.

Forced to Move raises anger which is necessary in order for people to react to this injustice. Out of the Ashes inspires faith and hope in the will to survive.

Cynthia Brown, editor

With Friends Like These:

The Americas Watch Report

on Human Rights \&

U.S. Policy in Latin America

Preface by Jacobo Timerman

Introduction by Alfred Stepan

Toronto: Random House, 1985

\section{by Alex Zisman}

Since its inception in 1981 the Americas Watch has been monitoring and promoting the observance of human rights in Latin America. It has periodically published reports and supplements on individual countries in the region. Often enough -- as in the case of the publications dealing with Guatemala, El Salvador and Honduras -- the exposure of human rights violations substantially relied on testimonies dealing with the plight of refugees. These reports and supplements were crisp, exceptionally informative and readily accessible to the general public. In With Friends Like These the collective effort of the Americas Watch contributors Cynthia Brown, Holly Burkhalter, Robert K. Goldman, Juan Méndez, Allan Nairn and Arye Neier not only follows but handily complements this previous body of work.

The massive flight of Central and South American refugees over the past decades responded -- and still responds -- to a coercive reality fostered by power groups which over the years have been refining and building on a legacy of social and economic inequalities and human rights abuses.

The United States may well have purported to act as a sort of godfather in the region, but, for all its democratic inclinations and sporadic attempts to encourage the improvement of standards of iiving and limit the disparity of wealth distribution, when forced to choose between social justice and the status quo, it almost invariably leaned towards the latter at the expense of the former. As a result, U.S. human rights guidelines in Latin America often proved contradictory. Despite some genuine concems for human rights

Continued ... 